\title{
Vil ei individklageordning til FNs barnekonvensjon innskrenke det demokratiske handlingsrommet til norske myndigheiter?
}

\author{
Ingrid Egeland Thorsnes
}

\begin{abstract}
Ingrid Egeland Thorsnes er seniorkonsulent ved Nasjonal institusjon, Norsk senter for menneskerettigheter (Universitetet i Oslo). Ho har tidlegare vore vitskapleg assistent same stad og var våren 2014 praktikant ved Noregs faste delegasjon til Europarådet i Strasbourg.
\end{abstract}

Artikkelen ${ }^{1}$ gir ei vurdering av kva konsekvensar ratifisering av den nye klageordninga til FNs barnekonvensjon vil kunne få for norske forhold. Det vert sett nærare på korleis barnekomiteen vil handsame individklagene, kva saker som eventuelt kan verte reist mot norske myndigheiter, samt kva materielle og prosessuelle verknader ordninga kan få i norsk rett.

\section{$1 \quad$ Innleiing}

Noreg har i mange år vore eit føregangsland på barnerettsfeltet og har for lengst gjennomført FNs barnekonvensjon i norsk rett. Då FNs generalforsamling ved-

1. Artikkelen byggjer på forfattaren si masteroppgåve hausten 2013 med tittelen «Individklageordning til FNs barnekonvensjon: Korleis kan klageordninga påverke norske myndigheiter sitt demokratiske handlingsrom?». 
tok tilleggsprotokollen om individklageordning i $2011,{ }^{2}$ var det derfor mange som såg det som sjølvsagt at Noreg skulle slutte seg til denne. Norske myndigheiter har imidlertid innteke ei skeptisk haldning til klagemekanismen, og tilleggsprotokollen tok derfor til å gjelde frå 14. april i år utan at Noreg er ein del av ordninga. ${ }^{3}$

Skepsisen frå myndigheitene si side synest i hovudsak å vere knytt til frykta for at klageordninga vil påverke makttilhøvet mellom politiske og rettslege organ på nasjonalt og internasjonalt nivå. ${ }^{4}$ Dette kan også formulerast som at myndigheitene ikkje ønskjer innskrenkingar i sitt demokratiske handlingsrom. Med demokratisk handlingsrom meinast dei avgjerdene folkevalde organ kan treffe utan omsyn til rettslege forpliktingar som allereie bind myndigheitene.

For å undersøkje korleis tilslutning til klageordninga kan påverke myndigheitene sitt handlingsrom vert det i det følgjande sett nærare på barnekomiteen si tolking av barnekonvensjonen, om ein kan forvente klagesaker mot norske myndigheiter, og kva desse klagene i så tilfelle vil omhandle. Vidare vil eg drøfte mogelege materielle og prosessuelle verknader av ratifisering. Ettersom fleire av problemstillingane handlar om situasjonar som ligg fram i tid, kan ein ikkje svare sikkert på desse spørsmåla. På grunnlag av dei rettskjeldene som finst og nokre enklare empiriske undersøkingar, er det likevel mogeleg å trekkje slutningar om kva som kan vere sannsynlege følgjer av tilslutning til klageordninga.

Spørsmålet om innskrenking av demokratisk handlingsrom inngår i ein større debatt om rettsleggjering. Med rettsleggjering meinast «at domstoler og andre rettsorganer får økende betydning på bekostning av folkevalgt myndighet, og at skillet mellom lovgivning og lovanvendelse blir visket ut». ${ }^{5}$ Spørsmålet om rettsleggjering har vore diskutert i mange år, men vart for alvor ein del av samfunnsdebatten då Makt- og demokratiutgreiinga kom med sin sluttrapport i NOU 2003: 19 Makt og demokrati. Ein av hovudkonklusjonane i rapporten var at det skjer ei rettsleggjering av det norske samfunnet, mellom anna ved at domstolane og

2. Generalforsamlingsresolusjon 66/138 (2011). Protokollen er per juni 2014 signert av 45 land og ratifisert av 11. Det tiande landet var Costa Rica, som ratifiserte protokollen i januar 2014, noko som medførte at klageordninga tok til å gjelde 14. april 2014, jf. tilleggsprotokollen artikkel 19.

3. Trine Skei Grande og Terje Breivik frå Venstre fremja forslag om tilslutning til tilleggsprotokollen i Stortinget 9. april 2014. Saka var gjenstand for open høyring 6. juni og er no til handsaming i utanriks- og forsvarskomiteen. Frist for komiteen til å gi innstilling er 22. oktober 2014.

4. Innlegg frå utanriksministeren i Stortinget (2012).

5. NOU 2003: 19, s. 58. 
internasjonale prøvingsorgan vert tilførde makt på kostnad av nasjonale politiske organ. $^{6}$

Det er mange interessante problemstillingar som reiser seg i tilknyting til individklageordninga. Av plassomsyn vert spørsmål om barn sine prosessuelle rettar, barn sin tilgang til domstolane og korleis nasjonale og internasjonale organ i praksis skal handtere klager frå barn, ikkje handsama i det følgjande.

\section{FNs barnekomité si tolking av barnekonvensjonen}

\subsection{Komiteen si tolking kan påverke myndigheitene sitt handlingsrom}

Korleis barnekomiteen tolkar konvensjonen, vil vere avgjerande for i kva grad klageordninga påverkar norsk rett. I denne samanhengen er det særleg to spørsmål som er av stor betyding: Om komiteen tolkar konvensjonen dynamisk, og kva skjønnsmargin statane vil verte innrømma ved komiteen si prøving av klagesakene.

\subsection{Dynamisk tolking}

Barnekomiteen uttalar i sin generelle kommentar nr. 8 at «the Convention, like all human rights instruments, must be regarded as a living instrument, whose interpretation develops over time». ${ }^{7}$ Barnekonvensjonen skal med andre ord tolkast dynamisk. I den nemnde kommentaren gir barnekomiteen også eit godt døme på slik dynamisk tolking: Barnekonvensjonen inneheld ikkje noko uttrykkjeleg forbod mot fysisk straffing av barn i oppsedingsføremål, men av komiteens generelle kommentar følgjer det likevel at statane etter konvensjonen har plikt til snarast mogeleg å forby all fysisk straffing av barn. ${ }^{8}$

Dynamisk tolking er ein akseptert og naudsynt del av tolkingsmetoden både i folkeretten og i norsk rett. ${ }^{9}$ Det kan likevel tenkjast tilfelle der dei internasjonale overprøvingsorgana går for langt i tolkinga av konvensjonen, og at statane

6. NOU 2003: 19, s. 30-33.

7. Barnekomiteens generelle kommentar nr. 8: «Barnets rett til beskyttelse mot fysisk avstraffelse og andre grusomme eller nedverdigende former for straff (bl.a. artikkel 19, artikkel $28 \mathrm{nr} .2 \mathrm{og}$ artikkel 37)» (2007) pkt. 20.

8. Barnekomiteens generelle kommentar nr. 8 (2007), pkt. 32 og Smith (2012), s. 26.

9. Ulfstein (2012b), s. 562 med vidare referansar. 
derfor finn at argumentasjonen deira ikkje er haldbar. ${ }^{10}$ Ei for dynamisk tolking av konvensjonen kan også føre til ei større myndigheitsoverføring frå nasjonale myndigheiter til barnekomiteen enn statane er villige til å akseptere. Går komiteen for langt i tolkinga av konvensjonen, kan det føre til at statane ikkje følgjer avgjerdene då desse ikkje er rettsleg bindande. For å unngå dette må den dynamiske tolkinga ha grunnlag i konvensjonen sin ordlyd og i praksis frå nasjonale eller internasjonale domstolar. ${ }^{11}$ Det er i denne samanhengen viktig å påpeike at det er barnekomiteen sjølv som vil stå for produksjonen av mykje av rettskjeldematerialet gjennom individklagesaker og generelle kommentarar. Slik vert det i stor grad komiteen som styrer rettsutviklinga på området. Dette må likevel skje over tid og basert på solid juridisk argumentasjon.

\subsection{Statane sin skjønnsmargin}

At komiteen innrømmer statane skjønnmargin, inneber at komiteen er tilbakehalden med å gå inn i vurderingane til dei nasjonale myndigheitene, så lenge staten oppfyller ein viss minimumsstandard.

Norske myndigheiter har særleg framheva viktigheita av skjønnsmargin i høve til dei økonomiske, sosiale og kulturelle (ØSK) rettane i konvensjonen. ${ }^{12}$ Bakgrunnen for dette synest å vere frykta for at barnekomiteen skal kunne påleggje staten plikt til å yte bestemte ytingar, til dømes innan utdanning eller helse, og på den måten leggje band på statlege midlar. Av protokollen artikkel $10 \mathrm{nr} .4$ følgjer det at komiteen ved handsaming av klager med påstand om krenking av ØSK-rettane i konvensjonen skal ta omsyn til at statane kan gjennomføre desse rettane med dei tiltak og verkemiddel dei sjølve ønskjer. ${ }^{13}$ Føresegna vart teken inn i protokollen nettopp av omsyn til dei statane som frykta at overprøving av ØSK-rettane skulle føre til betydelege inngrep i statane sitt politiske handlingsrom. ${ }^{14}$ Sjølv om det ikkje følgjer uttrykkjeleg av ordlyden i føresegna, viser forhandlingane i forkant at ein slik skjønnsmargin var ein føresetnad ved opprettinga av tilleggsprotokollen. ${ }^{15}$

\footnotetext{
10. Ulfstein (2012b), s. 562.

11. Smith (2012), s. 26.

12. Svar frå utanriksministeren i Stortingets spørjetime (2010).

13. Artikkel $10 \mathrm{nr} .4$ er identisk med føresegna som er teken inn i tilleggsprotokollen til FNs konvensjon om økonomiske-, sosiale- og kulturelle rettar artikkel 8 nr. 4.

14. Menneskerettighetsrådet (2011) pkt. 74 .

15. Elgesem (2013) s. 45-46.
} 
Spørsmålet er vidare om statane vil verte innrømma ein skjønnsmargin også for dei andre rettane i konvensjonen, altså dei sivile og politiske rettane, og for dei rettane som er særskilde for barnekonvensjonen, til dømes barnet sitt beste etter artikkel 3.

I motsetnad til i EMD, der ein lenge har operert med ein skjønnsmargin, er det ikkje avklart om det i FN-systemet eksisterer ein tilsvarande doktrine. Det vert hevda at sjølv om FNs menneskerettskomité sjeldan gir eksplisitt uttrykk for at dei nyttar ein skjønnsmargin, følgjer det av praksis at komiteen implisitt har lagt til grunn ei slik tilbakehalden tilnærming ved overprøving av vurderingar gjort av nasjonale myndigheiter. ${ }^{16}$

Det er fleire grunnar som talar for at statane vil verte innrømma ein viss skjønnsmargin også i høve til dei andre rettane i konvensjonen. For det første er barnekonvensjonen ein omfattande konvensjon som inneheld eit breitt spekter av rettar, noko som kan tale for at komiteen ikkje kan gå djupt inn i alle drøftingar som nasjonale myndigheiter har gjort. Vidare kan det vere vanskeleg å prøve saker fullt ut i dei tilfella der konvensjonsfråsegna er vagt formulert eller det er sterk usemje mellom medlemsstatane om kva som er det nærare innhaldet i rettane. Endeleg kan det tenkjast saker for komiteen, til dømes innanfor barnevern, der avgjerda på nasjonalt nivå vil vere treft på eit svært omfattande bevismateriale som komiteen ikkje har høve til å gjennomgå. I slike saker kan det vere vanskeleg for komiteen å prøve sakene fullt ut.

\section{$3 \quad$ Mogelege saker mot Noreg}

\subsection{Vil klageordninga verte nytta?}

Norske myndigheiter har allereie ratifisert klageordningane til FN-konvensjonane om sivile og politiske rettar, tortur, rasediskriminering og kvinnediskriminering. FN-komiteane har til saman realitetshandsama 11 saker mot Noreg og har funne at Noreg har handla i strid med konvensjonsforpliktingane totalt seks gonger. ${ }^{17}$ Det samla talet saker mot Noreg som er teke opp til handsaming, må seiast å vere

16. Legg (2012) s. 2 med vidare referansar.

17. Tal frå dokumentarkivet på heimesidene til FNs høgkommissær (http://tb.ohchr.org/) 11. mars 2014. 
relativt lite, noko som talar for at det heller ikkje vil kome svært mange klager inn til barnekomiteen.

Kor ofte barnekonvensjonen vert gjort gjeldande i norske domstolar, kan også gi ein viss indikasjon på omfanget av saker ein kan vente seg frå norske borgarar. Det knyt seg rett nok stor usikkerheit til å trekkje ei slik slutning, men synspunktet kan likevel vere eitt av fleire moment i vurderinga av om det er truleg at klageordninga vil verte nytta. Gjennomføringa av barnekonvensjonen i norsk rett har vore vellukka, ${ }^{18}$ og konvensjonen vert gjort gjeldande i norske rettssaker langt oftare enn dei andre FN-konvensjonane. ${ }^{19}$ Dette kan tale for at det vil kome nokre fleire klager til barnkomiteen enn det har gjort til dei andre FN-komiteane.

\subsection{Kva klager kan ein vente mot norske myndigheiter?}

Sjølv om det er vanskeleg å fastslå med sikkerheit kva type saker ein kan forvente mot norske myndigheiter, er det likevel ein del faktorar som kan indikere noko om kva ein kan vente. Særleg er det grunn til å tru at det vil kome saker på dei områda der Noreg er vorte kritisert av barnekomiteen, og der norske myndigheiter si tolking skil seg frå komiteen si tolking av konvensjonen. Vidare er det av interesse å sjå nærare på om norske myndigheiter har fått kritikk frå andre hald i spørsmål som vedkjem barnekonvensjonen, og i kva type saker konvensjonen vert gjort gjeldande for norske domstolar.

Etter ei gjennomgang av desse kjeldene er det grunn til å vente klager mot norske myndigheiter på ei rekkje område, mellom anna diskriminering, barn i fengsel, psykisk helse og mobbing. Det er likevel eitt område som skil seg ut som særleg aktuelt, nemleg utlendingsfeltet. På dette området kan det mellom anna tenkjast klager som gjeld barnet sitt beste versus innvandringsregulerande omsyn, barnet sin rett til å verte høyrt og saker som gjeld helse, skule og fritid for asylsøkjande barn. Barnekomiteen framheva i dei avsluttande merknadene til Noreg i 2010 særleg behovet for vern av asylbarn. ${ }^{20}$

18. Smith (2012) s. 27.

19. Undersøkinga byggjer på eigne søk i Lovdata.no og er utdjupa i oppgåva som ligg til grunn for artikkelen.

20. Barnekomiteens avsluttande merknader til Noreg (2010) s. 11-12. 


\section{$4 \quad$ Materielle verknader av klageordninga}

\subsection{Etterleving av barnekomiteens avgjerder mot Noreg}

Med materiell verknad meiner eg her korleis ratifiseringa av tilleggsprotokollen kan påverke norsk lovgiving, rettspraksis, budsjettvedtak og andre politiske vedtak. Avgjerande for verknaden av klageordninga i så måte er om avgjerdene frå komiteen vil verte etterlevd av norske myndigheiter, og kva rettskjeldevekt avgjerdene frå komiteen vil ha i norsk rett .

Avgjerdene frå komiteen er ikkje folkerettsleg bindande. Av protokollen artikkel $11 \mathrm{nr} .1$ følgjer det at statane er forplikta til å «give due consideration to the views of the Committee». Det vil etter ordlyden vere tilstrekkeleg å gjere ei grundig vurdering av avgjerdene frå komiteen. På den andre sida vil det at barnekomiteen finn at det ligg føre ei krenking, vere ein tungtvegande indikasjon på at barnekonvensjonen, som er folkerettsleg bindande, er krenka. ${ }^{21}$ Noreg har så langt følgt fem av seks avgjerder frå FN-komiteane mot Noreg, ${ }^{22}$ og det er derfor truleg at også avgjerdene frå barnekomiteen vil verte etterlevde.

\subsection{Rettskjeldevekt}

I dommen som er innteken i Rt. 2008 s. 1764 (Restauratørsaka), drøfta Høgsterett i plenum spørsmålet om kva vekt ein skulle leggje på ei avgjerd frå FNs menneskerettskomité som rettskjelde i norsk rett. Menneskerettskomiteen hadde tidlegare same år kome til at manglande grunngiving for ankenekting representerte eit brot på FN-konvensjonen om sivile og politiske rettar artikkel 14. Høgsterett konkluderte med at ein skulle leggje «betydeleg vekt» på avgjerda frå menneskerettskomiteen. Ettersom barnekomiteen har tilsvarande rolle ved overvaking av gjennomføringa av konvensjonen, og sidan begge komiteane nyttar om lag same sakshandsamingsreglar, talar mykje for at same vekt må leggast på avgjerdene frå barnekomiteen. ${ }^{23}$ Med omsyn til at domstolane skal tolke barnekonvensjonen ut

21. Elgesem (2013), s. 19.

22. Unntaket var i Dar-saka (Rt. 2008, s. 513), der Høgsterett ikkje var einig i torturkomiteen si avgjerd om at komiteen kunne avseie bindande mellombelse avgjerder. Saken handla om ein asylsak og enda med at familien fekk vere i landet etter at det var lagt fram ny informasjon i etterkant av avgjerda frå Høgsterett.

23. I same retning: Elgesem (2013), s. 20-21 og Ulfstein (2012a), s. 99. 
frå det rettskjeldematerialet som ligg føre, vil dette gjelde uavhengig av Noregs tilslutning til tilleggsprotokollen.

\section{Prosessuelle verknader av klageordninga}

\subsection{Rettsleg handheving av barnekonvensjonen}

I det følgjande vert det sett nærare på korleis saker om krenking av barnekonvensjonen per i dag kan prøvast for norske domstolar, og korleis tilslutning til klageordninga kan tenkjast å påverke dette.

Eit av spørsmåla som har vore oppe i samband med spørsmålet om tilslutning til tilleggsprotokollen, er om enkelte av konvensjonsføresegnene i det heile kan overprøvast rettsleg. ${ }^{24}$ I denne samanhengen er det særleg to omgrep som vert nytta. Det eine er om rettane i konvensjonen er «justiciable», og det andre er om rettane har sjølvkraft. Kva som ligg i omgrepa, er ikkje eintydig, samstundes som dei delvis overlappar kvarandre.

At ei føresegn er «justiciable», kan kort forklarast som at ho kan handhevast rettsleg. ${ }^{25}$ For å avgjere om ei føresegn kan handhevast rettsleg, må ein vurdere om det temaet føresegna regulerer, er eigna for rettsleg overprøving. Konsekvensen av at konvensjonsføresegnene ikkje kan handhevast rettsleg, må vere at dei korkje kan prøvast av nasjonale domstolar eller ved individklager til barnekomiteen. Spørsmålet er særleg relevant for ØSK-rettane i konvensjonen. Det vert hevda at desse føresegnene ikkje kan handhevast rettsleg fordi dei regulerer spørsmål som i eit demokrati er underlagt politisk, ikkje rettsleg, styring. ${ }^{26}$ Dette vert grunngjeve med at oppfylling av desse rettane kan leggje band på store delar av dei økonomiske midlane staten har til rådvelde.

Spørsmålet om ei føresegn kan handhevast rettsleg, heng saman med spørsmålet om føresegna har sjølvkraft, men er ikkje det same. ${ }^{27}$ At ei føresegn har sjølvkraft, inneber at ho etter sitt innhald er eigna til å verte nytta som sjølvstendig rettsgrunnlag for domstolane eller andre rettshandhevingsorgan utan å vere

24. Elgesem (2013), s. 16-17.

25. Khaliq og Churchill (2012), s. 200.

26. Khaliq og Churchill (2012), s. 200.

27. Sjå ØSK-komiteen sin generelle kommentar nr. 9 pkt. 10, Harborg (2011), s. 28 og Søvig (2009), s. 31. Elgesem (2013) synest i sin rapport ikkje å skilje mellom dei to omgrepa, sjå s. 38. 
presisert gjennom nasjonal lovgiving. ${ }^{28}$ Spørsmålet om ei føresegn har sjølvkraft, kan også formulerast som eit krav til klarleik: Er innhaldet i føresegna tilstrekkeleg klart til at ein utleie konkrete rettar og plikter av henne, kan føresegna nyttast som rettsleg grunnlag for nasjonale domstolar. ${ }^{29}$

Konvensjonsføresegner må på same måten som nasjonal lovgiving tolkast i lys av andre relevante rettskjelder. Nasjonal rettspraksis og avgjerder frå internasjonale domstolar og prøvingsorgan kan bidra til at innhaldet i ei konvensjonsføresegn vert klargjort. Om ei føresegn i ein konvensjon har sjølvkraft, er derfor ikkje nokon uforanderleg situasjon. ${ }^{30}$ Når det ligg føre fleire relevante rettskjelder til bruk ved tolking av føresegna, kan det verte lettare å fastsetje innhaldet slik at sjølvkraft kan konstaterast.

Det kan hevdast at bruk av desse to omgrepa er ein kompliserande faktor dersom målet er å handheve rettane i konvensjonen effektivt. ${ }^{31}$ Norske domstolar må i tråd med tradisjonell rettskjeldelære tolke konvensjonsføresegnene ut frå relevante rettskjelder. Kan ein utleie konkrete rettar og plikter frå føresegnene, kan desse nyttast som sjølvstendig rettsgrunnlag i nasjonale domstolar. Kan ein ikkje utleie slike bestemte rettar og plikter, må innhaldet i føresegnene presiserast i nasjonal lovgiving.

Det er ikkje høve til å gå inn på dei einskilde føresegnene i barnekonvensjonen her, men etter mi meining er det ikkje tvilsamt at desse i hovudsak har eit rettsleg tema og derfor kan handhevast i domstolar og klageorgan. Dette må også vere sjølve premissen bak opprettinga av ei individklageordning. Enkelte av føresegnene har likevel ei vag og uklar formulering som gjer dei lite eigna som sjølvstendig rettsgrunnlag i norsk rett. Det kan derfor tenkjast at saker om brot på konvensjonen kan verte avviste frå norske domstolar fordi konvensjonsføresegna ikkje kan nyttast som rettsleg grunnlag. Det er her ein flytande overgang til søksmålsvilkåra i den norske tvistelova.

Vilkåra for å gå til sivil sak i norske domstolar følgjer av tvl. $\$ 1-3$ : Saker som skal reisast for domstolane, må etter første ledd gjelde «rettskrav», og etter andre ledd må saksøkjar ha eit «reelt behov» for å få saka avgjort. Om saksøkjar har

28. Smith (2012), s. 24 .

29. I same retning Reusch (2013).

30. Søvig (2009), s. 31.

31. På same måte som Søvik (2009), s. 31. 
eit «reelt behov», vert avgjort ut frå ei «samlet vurdering av kravets aktualitet og partenes tilknytning til det».

Søksmål om brot på barnekonvensjonen kan reisast på ulike måtar. Døme på saker som kan oppfylle vilkåra i tvistelova, kan vere søksmål om gyldigheita av forvaltningsvedtak og erstatningssøksmål for manglande vern, til dømes i mobbesaker. I andre samanhengar kan det vere meir usikkert om spørsmålet om konvensjonskrenking oppfyller vilkåra, til dømes fordi situasjonen ikkje lenger er aktuell. Vedtaket eller avgjerda saka gjeld, kan vere oppheva, og ein har slik ikkje lenger eit «reelt behov» for å få saka handsama. Spørsmålet vert då om domstolane likevel kan avseie fastsetjingsdom for brot på barnekonvensjonen.

Dette spørsmålet kom opp i plenumsdommen Rt. 2012 s. 2039, som mellom anna omhandla spørsmålet om Utlendingsnemnda hadde teke tilstrekkeleg omsyn til barnet sitt beste etter artikkel 3 i vedtak om utvisning. Fleirtalet i Høgsterett uttala at det ikkje følgjer av våre internasjonale forpliktingar at domstolane må gi fastsetjingsdom for brot på barnekonvensjonen, og kom derfor til at spørsmålet måtte løysast på bakgrunn av tvl. $\$ 1-3$. Etter ein gjennomgang av forarbeida og kommentarane til tvistelova kom Høgsterett til at barnekonvensjonen ikkje inneheld eit krav om effektivt rettsmiddel, noko som tala mot at saksøkjaren hadde krav på fastsetjingsdom. Førstvoterande uttala vidare at saka heller ikkje omhandla eit «rettskrav», eller at det var eit «reelt behov» for at domstolane særskilt skulle prøve spørsmålet om det låg føre ei krenking av artikkel 3. Konklusjonen vart følgjeleg at det ikkje kunne avseiast dom for brot på barnekonvensjonen artikkel 3. Slik rettstilstanden er i dag, er det etter dette ikkje høve til å få avsagt fastsetjingsdom for brot på barnekonvensjonen med mindre saka oppfyller vilkåra i tvl. $\$ 1-3 .{ }^{32}$

Hadde ein kunne utleda eit krav om effektivt rettsmiddel fra barnekonvensjonen ville situasjonen ifølgje argumentasjonen frå Høgsterett ha stilt seg noko annleis. Av tilleggsprotokollen artikkel 7 følgjer det at alle nasjonale rettsmiddel skal vere uttømde før ei klage kan rettast til komiteen, med unntak for når sakshandsaminga på nasjonalt nivå tek urimeleg lang tid eller rettsmiddelet ikkje gir effektivt vern. Føresegna gir etter mitt skjønn ikkje rett på effektivt rettsmiddel, men fastset at der effektivt rettsmiddel ikkje ligg føre, kan borgaren ta saka direkte inn for komiteen.

32. Elgesem (2013) foreslår ei endring av føresegna ved ein eventuell ratifikasjon, s. 71. 


\subsection{Utvida prøving av barnekonvensjonen etter tilslutning til klageordninga?}

Etter drøftingane over inneheld korkje barnekonvensjonen eller tilleggsprotokollen eit krav om effektivt rettsmiddel. Fleire av føresegnene i konvensjonen er ikkje presise nok til å verte nytta som rettsgrunnlag i norske rettssaker, og saker som gjeld krenkingar av barnekonvensjonen, vil kunne verte avviste frå handsaming i norske domstolar på grunn av at sakene ikkje oppfyller søksmålsvilkåra i tvistelova. Ein kan derfor sjå føre seg at ei rekkje saker om krenking av barnekonvensjonen vil verte avviste frå nasjonale domstolar.

Som nemnd over, følgjer det av tilleggsprotokollen artikkel 7 at når ein ikkje får prøvd sakene sine på nasjonalt nivå, kan desse takast direkte inn for komiteen. Ein får etter dette ein situasjon der saker kan klagast inn for komiteen utan først å ha vore handsama i norske domstolar. Ei slik løysing vil stride sterkt mot subsidiaritetsprinsippet, som går ut på at avgjerder i utgangspunktet skal treffast så nært partane i saka som mogeleg, altså nasjonalt heller enn internasjonalt. ${ }^{33}$

På same måte som barnekonvensjonen inneheld heller ikkje FNs konvensjon om økonomiske sosiale og kulturelle rettar eit krav om effektivt rettsmiddel. Henning Harborg finn i sin rapport om individklageordning til ØSK-konvensjonen at prøving av rettane på nasjonalt nivå før dei eventuelt vert klaga inn for komiteen, må verte løysinga ved ei eventuell tilslutning til klageordninga. ${ }^{34}$ Eg meiner at det same må gjelde for barnekonvensjonen. Etter mitt skjønn vil det vere uheldig for både staten og barnekomiteen om sistnemnde skal gå lenger i si prøving av statane si oppfylling av konvensjonen enn det nasjonale myndigheiter gjer. For det første vil det føre til større maktoverføring frå nasjonale myndigheiter, og for det andre vil det innebere ein fare for ei større arbeidsbyrde for komiteen. Ei utvida prøving frå domstolane si side vil kunne medføre at norske domstolar i større utstrekning enn tidlegare vil vurdere oppfyllinga av rettane i barnekonvensjonen, kanskje særleg dei typiske ØSK-rettane, som i dag vert prøvde i liten grad.

33. Ulfstein og Føllesdal (2012), s. 447.

34. Harborg (2011), s. 103-104. I same retning Elgesem (2013), s. 68. 


\section{Avslutning}

Etter mi meining vil ratifisering av tilleggsprotokollen føre til ei viss innskrenking av det demokratiske handlingsrommet til myndigheitene. Dette skjer på to nivå: For det første skjer det ei maktoverføring frå nasjonalt til internasjonalt nivå ved at barnekomiteen truleg vil finne at norsk rett ikkje alltid er i tråd med konvensjonen, og at avgjerdene frå barnekomiteen med stort sannsyn vil verte etterlevde av norske myndigheiter og domstolar. Avgjerdene frå komiteen vil også verte tillagde vekt som rettskjelde i andre saker. For det andre vil det på nasjonalt nivå skje ei viss myndigheitsoverføring frå politiske organ til domstolane, som truleg vil prøve barnekonvensjonen oftare enn tidlegare. Det området som vil verte mest påverka av tilslutninga vil truleg vere utlendingsfeltet. Sjølv om tilslutning vil føre til noko maktoverføring, er det viktig å minne om at Noreg allereie oppfyller konvensjonen på eit høgt nivå, og at eventuelle innskrenkingar derfor neppe vert av dramatisk karakter.

Kjeldelista er tilgjengeleg i masteroppgåva som ligg til grunn for artikkelen: https:// www.duo.uio.no/handle/10852/38522 